\title{
SURVEY OF SCALE INSECTS AND MEALYBUGS INFESTING SOME AVOCADO CULTIVARS AND THEIR ASSOCIATED NATURAL ENEMIES IN EGYPT
}

\author{
YOUSSEF, A. S. and A. M. SERAG
}

Plant Protection Research Institute, ARC, Dokki, Giza

(Manuscript received 5 November 2014)

\begin{abstract}
$\mathrm{T}$ he present work was conducted for one year (January December, 2013) on six avocado cultivars cultivated in new reclaimed lands at Borg El Arab (Alexandria Governorate), El Bostan (Beheira Governorate), El Sadat (Menofiya Governorate) and Sarapium (Ismailiya Governorate). The study was conduct to survey the scale insect and mealybug species and their associated natural enemies as well as the degree of infestation on avocado trees. The obtained results revealed eight species of scale insects and Mealybugs. Two coccid species [Coccus hesperidum L. and Pulvinaria psidii (Mask.)], Four diaspidid species [Hemiberlesia lataniae (Sign.), Aulacaspis tubercularis (Newst)., Aonidiella aurantii (Mask.) and Aspidiotus nerii Bouche] and Two Pseudococcid species [Pseudococcus longispinus (Targ.-Tozz.) and Ferrisia virgata (Ckll.)]. Associated parasitoids were Coccophagus scutellaris on C. hesperidum, Aphytis lepidosaphes, Habrolepis aspidioti and Marietta leopardina on $H$. lataniae, Encarsia citrina and Habrolepis diaspidi on A. tubercularis and Anagyrus spp. on $P$. longispinus. Also, associated predators were Rodalia cardinalis on C. hesperidum and two coccinellid predators (Cryptolaemus montrouzieri and Scymnus syriacus) on P. longispinus. H. lataniae was the most abundant (56.8\%) followed by $F$. virgata (42.5\%), A. tubercularis (39.8\%) , P. longispinus (31.7\% ), C. hesperidum (26.6\%), P. psidii (15\%), A. aurantii (15\%) and A. nerii (14.3\%). Hass cultivar proved the highest infestation rate in the four localities followed by Boothy and Waldim cultivars. Fuerte, Gwen and Lula cultivars had the lowest infestation rate.
\end{abstract}

\section{INTRODUCTION}

Avocado, Persea americana Mill (family Lauraceae) is evergreen trees and native to Central and South America, it grown in most tropical and subtropical areas. Avocado fruits are a rich source in vitamins and minerals. The fruits mature on the tree and ripen off of the tree in a few days when stored at room temperature.

Avocado trees are attacked with many scale insect and mealybug species worldwide as Colombia (Foldi and Watson, 2001, Gil et al., 2007, Kondo, 2010 and 
Kondo et al., 2012), USA (Rugman-Jones et al., 2009), Chile (Navea and Vargas, 2012), Mexico (Lazaro-Castellanos et al., 2012) and Israel (Swirski \& Wysoki, 1995).

Scale insects and mealybugs causing considerable reduction in quantity and quality of avocados crop. Hemiberlesia lataniae (Signorte) infested up to $34 \%$ of the fruits during 1991-92 in New Zealand (Blank et al., 1994). However, scale insects, Abgrallaspis aguacatae and Hemiberlesia lataniae were occasional pests of Hass cultivar in Mexico but they can cause problems during the production and packing of the fruits (Hernandez-Rivero et al., 2013).

In Egypt, many avocado cultivars have been cultivated in new reclaimed lands in Borg El Arab (Alexandria Governorate), El Bostan (Beheira Governorate), El Sadat (Menofiya Governorate) and Sarapium (Ismailiya Governorate) and up to date no official records for avocado pests in Egypt for scale insect and mealybug species is available. The present work was conducted to survey the scale insect and mealybug species on avocado cultivars as well as their associated natural enemies and degree of infestation with the scale pests.

\section{MATERIALS AND METHODS}

Survey of scale insects and mealybugs on avocado cultivars cultivated in new reclaimed lands were carried out for one complete year (January - December, 2013) in Borg El-Arab (Alexandria Governorate), El-Bostan (Beheira Governorate), El-Sadat (Menofiya Governorate) and Sarapium (Ismailiya Governorate). Monthly samples (20 leaves, 4 twigs $/ 20 \mathrm{~cm}$ long) and 4 avocado fruits) were collected randomly from avocado trees. The study was conducted on six cultivars i.e. .Hass, Lula, Fuerte, Boothy, Gwen and Waldim as follows: El-Bostan (Boothy, Fuerte, Hass and Waldim), El Sadat (Boothy, Fuerte, Hass and Lula), Borg El Arab (Gwen, Lula and Waldim) and Sarapium (Gwen, Hass and Waldim). Collected samples were transferred to laboratory in paper bags for inspection. The scale insects and mealybugs were identified and sorted to different stages. After examined the leaves and twigs of avocado cultivars per each sample, some specimens from each scale species were confined in glass jars and kept in the laboratory for securing any emerging parasitoids. The surveyed scale insect and mealybug species and their natural enemies were identified in the Scale Insects and Mealybugs Division, Plant Protection Research Institute, Agricultural Research Center.

Degree of infestation with the scale insect and mealybug species was determined according to equation recorded by Facylate (1971):

Degree of infestation $=(n / N) \times 100$ 
Where:

$\mathrm{n}=$ Number of infested samples.

$\mathrm{N}=$ Total number of samples.

The surveyed scales were classified to three categories according to their percent of infestation as follows:

- Heavy infestation when percentages more than $50 \%$.

- Medium infestation when percentages between $25-50 \%$.

- Low infestation when percentages between 1 -25\%.

\section{RESULTS AND DISCUSSION}

\section{Surveyed scale insect and mealybugs}

The obtained results (Table 1 ) revealed 8 species of scale insect and mealybugs on avocado cultivars at four localities (Borg El-Arab, El-Bostan, El-Sadat and Sarapium).The Surveyed species belonging to three families as follows:

Table 1. Scale insect and mealybug species recorded on different parts of avocado cultivars at four localities in the new reclaimed lands (January - December, 2013).

\begin{tabular}{|c|c|c|}
\hline Family & Common name & Scientific name \\
\hline \multirow{2}{*}{ Coccidae } & Soft brown scale & Coccus hesperidum $\mathrm{L}$. \\
\hline & Green shield scale & Pulvinaria psidii Mask. \\
\hline \multirow{4}{*}{ Diaspididae } & Latania scale & Hemiberlesia lataniae (Sign.) \\
\hline & White mango scale & Aulacaspis tubercularis (Newst.) \\
\hline & California red scale & Aonidiella aurantii (Mask.) \\
\hline & Oleander scale & Aspidiotus nerii Bouche. \\
\hline \multirow{2}{*}{ Pseudococcidae } & Long-tailed mealybug & Pseudococcus longispinus (Targ. -Tozz.) \\
\hline & Striped mealybug & Ferrisia virgata (Ckll.) \\
\hline
\end{tabular}

\section{Family: Coccidae}

Two coccid species were recorded at the four localities i.e. the soft brown scale, Coccus hesperidum $\mathrm{L}$ and green shield scale, Pulvinaria psidii (Mask.). These species suck the plant sap of leaves and secreted a large amount of honeydew which encourages the growth of sooty mould fungus. In addition, the infested trees became dirty black appearance which affected on photosynthesis and respiration processes. Swirski and Wysoki (1995) recorded the pyriform scale, Protopulvinaria pyriformis (Ckll.) on avocado trees in Israel. Kondo (2010) recorded a new soft scale insect, Bombacoccus aguacatae Kondo from the branches and twigs of avocado cultivated in Colombia South America. 


\section{Family: Diaspididae}

Four diaspidid species were recorded on different parts of avocado cultivars at the four localities. They were Lataniae scale, $H$. lataniae, white mango scale, $A$. tubercularis, California red scale, $A$. aurantii and Oleander scale, $A$. nerii. The recorded species occurs on leaves, twigs and fruits and causes colored spots on the leaves and fruits of avocado cultivars. The infested leaves will be drop prematurely not only due to feeding on plant sap but also due to toxicity of saliva of some species as the white mango scale, A. tubercularis (Pena et al., 1997), Heavy infested avocado trees appear unhealthy and grow poorly

In USA, Rugman-Jones et al. (2009) found six diaspidid species infesting avocado fruits (Hass cultivar) in California they were Abgrallaspis aguacatae Evans, Watson \& Miller, H. lataniae, Hemiberlesia sp. near lataniae, Hemiberlesia. rapax (Comstock), Acutaspis albopicta (Ckll.), and Pinnaspis strachani (Cooley) besides two another additional species, Diaspis miranda (Ckll.) and Diaspis sp. near Miranda. Navea and Vargas (2012) revealed that Hemiberlesia lataniae becomes a major pest of avocado in Chile and reached high populations in the fruits because of limited natural control.

Lazaro-Castellanos et al. (2012) reported three armored scales (H. lataniae, $A$. aguacatae and $H$. rapax) infesting avocado leaves, branches and fruits in Mexico. They reported Encarsia citrina to parasitize these armored scale species and had better potential in management of armored scales and present most of the year. However, Hernandez-Rivero et al. (2013) showed that, the armored scales ( $A$. aguacatae and $H$. lataniae) were occasional pests of Hass cultivar in Mexico but they can cause problems during the production and packing of the fruits.

\section{Family: Pseudococcidae}

Two Pseudococcid species were recorded on the fruit of avocado trees, the long-tailed mealybug, P. longispinus and the striped mealybug, F. virgata. They sucking the plant sap and secreting honeydew which leads to growth of sooty mould. The black fungus coats the upper surface of leaves interfering with photosynthesis. In this respect, Swirski and Wysoki (1995) reported that, the long-tailed mealybug, $P$. longispinus is a pest on avocado trees in Israel.

\section{Natural enemies associated with avocado scales}

Results in Table (2) revealed the parasitoids and predators associated with surveyed scale insect and mealybug species on avocado cultivars at four localities as follows: 
Coccid pests: The soft brown scale, $C$. hesperidum associated with one aphelinid parasitoid, C. scutellaris and green shield scale, P. psidii associated with one coccinellid predator, $R$. cardinalis.

Diaspidid pests: The latania scale, $H$. lataniae associated with three aphelinid parasitoids (i.e. A. lepidosaphes, H. aspidioti and M. leopardina) whereas the white mango scale $A$. tubercularis was associated with the Aphelinid parasitoid, E. citrina and the encyrtid parasitoid, $H$. diaspidi. California red scale $A$. aurantii associated with the aphelinid parasitoid, A. maculicornis and the oleander scale $A$. nerii was associated with the encyrtid parasitoid, $H$. aspidioti.

Pseudococcid pests: The long-tailed mealybug, $P$. longispinus was associated with encyrtid parasitoids, Anagyrus spp. whereas the striped mealybug, F. virgata has two coccinellid predators $C$. montrouzieri and $S$. syriacus.

\section{Abundant of scale insect and mealybug species on avocado trees}

The abundant of scale insect and mealybug species on avocado trees in the four localities were noticeably varied (Fig. 1). The highest abundant scale on avocado trees in the four localities was $H$. lataniae as $56.8 \%$ followed by $F$. virgata and $A$. tubercularis (42.5\% and $39.8 \%$, respectively). P. longispinus and $C$. hesperidum came in the $4^{\text {th }}$ order and presented by $31.7 \%$ and $26.6 \%$. P. psidii, A. aurantii and $A$. nerii had lower percentages of all collected species in the four localities, they came in the last order and presented by $15 \%, 15 \%$ and $14.3 \%$ respectively.

Table 2. Natural enemies associated with scale insects and mealybugs recorded on avocado cultivars at four localities in the new reclaimed lands (JanuaryDecember, 2013).

\begin{tabular}{|c|c|c|}
\hline Insect pest & \multicolumn{2}{|c|}{$\begin{array}{l}\text { Associated parasitoids and predators with their families } \\
\text { names and orders }\end{array}$} \\
\hline Coccus hesperidum $\mathrm{L}$. & Coccophagus scutellaris & Aphelinidae - Hymenoptera \\
\hline Pulvinaria psidii Mask. & Rodalia cardinalis & Coccinellidae - Coleoptera \\
\hline \multirow{3}{*}{ Hemiberlesia lataniae (Sign.) } & Aphytis lepidosaphes & \multirow{3}{*}{ Aphelinidae - Hymenoptera } \\
\hline & Habrolepis aspidioti & \\
\hline & Marietta leopardina & \\
\hline \multirow{2}{*}{ Aulacaspis tubercularis (Newst.) } & Encarsia citrina & Aphelinidae - Hymenoptera \\
\hline & Habrolepis diaspidi & Encyrtidae - Hymenoptera \\
\hline Aonidiella aurantii (Mask.) & Aphytis maculicornis & Aphelinidae - Hymenoptera \\
\hline Aspidiotus nerii Bouch. & Habrolepis aspidioti & Encyrtidae - Hymenoptera \\
\hline Pseudococcus longispinus (Targ.-Tozz) & Anagyrus spp. & Encyrtidae - Hymenoptera \\
\hline \multirow{2}{*}{ Ferrisia virgata (Ckll.) } & Cryptolaemus montrouzieri & \multirow{2}{*}{ Coccinellidae - Coleoptera } \\
\hline & Scymnus syriacus & \\
\hline
\end{tabular}

\section{Degree of infestation}

Degree of infestation with scale insect and mealybug species on avocado cultivars was presented in Table (3) and illustrated in Fig. (2). The obtained results 
showed different infestation with scale insect and mealybug species on avocado cultivars cultivated at Borg El-Arab (Alexandria Governorate). The Hass cultivar had the heaviest infestation with scale insect and mealybug species followed by Waldim cultivar with medium infestation whereas Fuerte, Gwen and Lula cultivars had lower infestation rate.

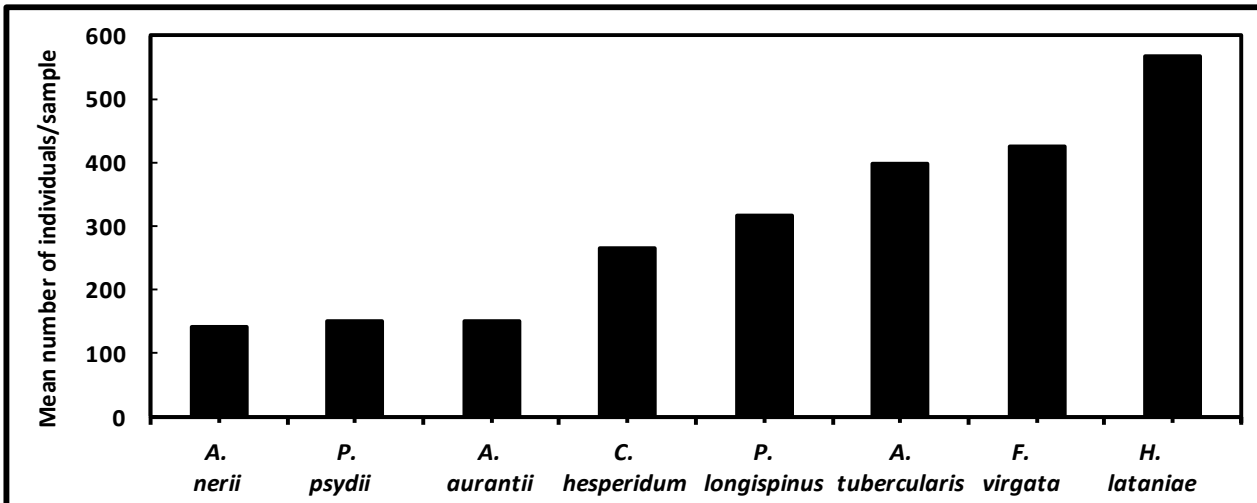

Fig. (1): Abundant of scale insect and mealybug species on avocado trees (January- December).

In El-Bostan locality at Beheira Governorate Hass cultivar showed heavy infestation with scale insect and mealybug species followed by Boothy and Waldim cultivars with medium infestation while Fuerte and Gwen cultivars have lower infestation with scale insect and mealybug species.

In El-Sadat locality at Menofiya Governorate Hass cultivar showed heavy infestation with scale insect and mealybug species followed by Boothy cultivar with medium infestation while Fuerte and Lula cultivars have lower infestation with scale insect and mealybug species.

In Sarapium locality at Ismailiya Governorate Hass cultivar showed heavy infestation by scale insect and mealybug species followed by Waldim cultivar with medium infestation while Fuerte and Gwen cultivars have lower infestation with scale insect and mealybug species.

Generally, Hass cultivar proved to be the highest infestation with scale insect and mealybug species in the four localities in the new reclaimed lands followed by Boothy and Waldim cultivars whereas Fuerte, Gwen and Lula cultivars were the lowest in this respect. Wysoki et al. (1977) graded the common avocado varieties grown in Israel in descending order of susceptibility to Pseudococcus longispinus as follows: Hass, Nabal, Fuerte and Ettinger cultivar. 
Table 3. Degree of infestation with scale insect and mealybug species on different avocado cultivars cultivated in the different localities in the new reclaimed lands.

\begin{tabular}{|c|c|c|c|}
\hline Governorate & Locality & Avocado cultivar & Degree of infestation \\
\hline \multirow{5}{*}{ Alexandria } & \multirow{5}{*}{ Borg El- Arab } & Hass & Heavy \\
\hline & & Waldim & Medium \\
\hline & & Fuerte & Low \\
\hline & & Gwen & Low \\
\hline & & Lula & Low \\
\hline \multirow{5}{*}{ Beheira } & \multirow{5}{*}{ El- Bostan } & Hass & Heavy \\
\hline & & Boothy & Medium \\
\hline & & Waldim & Medium \\
\hline & & Fuerte & Low \\
\hline & & Gwen & Low \\
\hline \multirow{4}{*}{ Menofiya } & \multirow{4}{*}{ El- Sadat } & Hass & Heavy \\
\hline & & Boothy & Medium \\
\hline & & Lula & $\mathrm{Low}$ \\
\hline & & Fuerte & Low \\
\hline \multirow{4}{*}{ Ismailiya } & \multirow{4}{*}{ Sarapium } & Hass & Heavy \\
\hline & & Waldim & Medium \\
\hline & & Fuerte & Low \\
\hline & & Gwen & Low \\
\hline
\end{tabular}

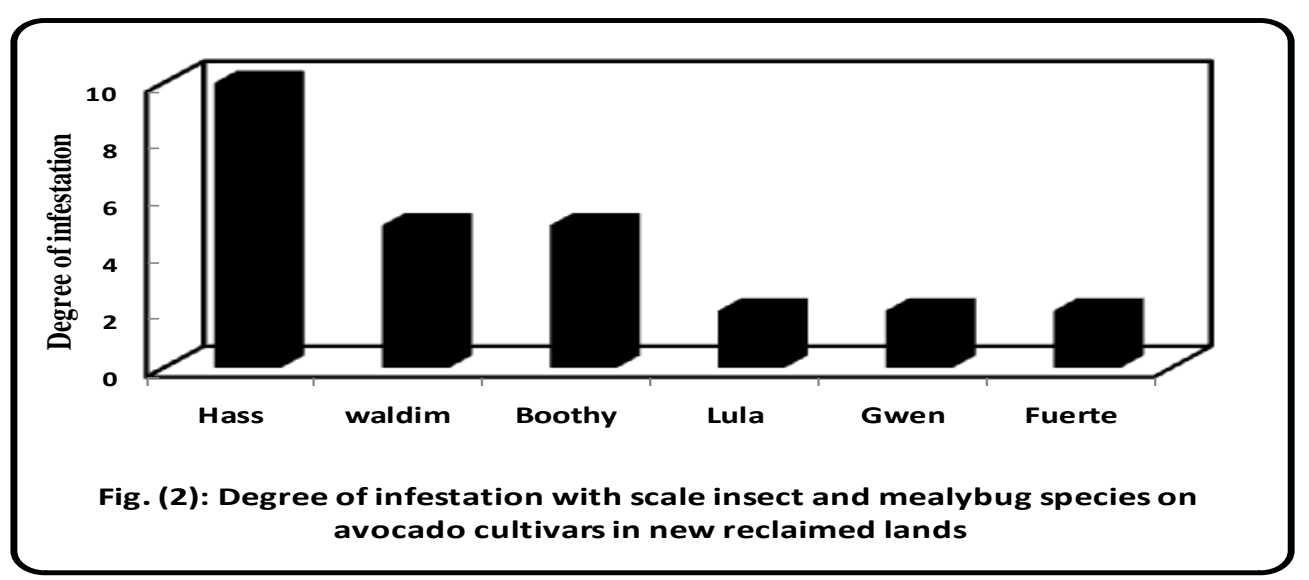

Foldi and Watson (2001) recorded Laurencella colombiana (Hemiptera: Margarodidae) as a new scale insect pest of avocado trees in Colombia and is becoming increasingly important at altitudes over 2000 meters above sea level, killing branches by excessive extraction of plant sap and reducing productivity by causing development of sooty mould on leaves and fruit. Recently, Kondo et al. (2012) reported the multicicatrices fluted scale, Crypticerya multicicatrices. Kondo and Unruh (Hemiptera: Monophlebidae) from the islands of San Andres and Providence of Colombia as a recent invasive species on avocado and numerous plants of economic importance. 


\section{REFERENCES}

1. Blank, R., Olson, M., Gill, G. and J. Clark. 1994. Latania scale establish on avocados during pollination. Orchardist of New Zealand, 67(4):28-30.

2. Facylate, K. K. 1971. Field studies of soil invertebrates 2nd Edition, Vishia Shkoola Press, Moscow, USSR: 424 pp.

3. Foldi, I. and G. W. Watson. 2001. A new pest scale insect on avocado trees in Colombia, Laurencella colombiana, sp. n. (Hemiptera: Coccoidea: Margarodidae). Annales de la Societe Entomologique de France, 37(3):367-374.

4. Gil, P. Z. N., Posada F. F. J., Perez S. M., and M. R. Cardenas. 2007. Record and bionomic notes of a new avocado pest Laurencella colombiana (Hemiptera: Margarodidae) in Colombia. Revista U.D.C.A. Actualidad \& Divulgacion Cientifica, $10(2): 43-50$.

5. Hernandez-Rivero, R., Arevalo-Galarza, M. de L. C., Valdovinos-Ponce, G., Gonzalez-Hernandez, H., Vz-Carrasco, J. and M. E. Ramirez-Guzman. 2013. Histology of the damage in fruits and branches of 'Hass' avocado trees caused by armored scales (Hemiptera: Diaspididae). Revista Mexicana de Ciencias Agricolas, 4(5):739-752.

6. Kondo, T. 2010. Description of a new coccid (Hemiptera: Coccidae) on avocado (Persea americana Mill.) from Colombia South America. Zookeys, (42):37-45.

7. Kondo, T., Gullan, P. and A. A. Ramos Portilla. 2012. Report of new invasive scale insects (Hemiptera: Coccoidea), Crypticerya multicicatrices Kondo and Unruh (Monophlebidae) and Maconellicoccus hirsutus (Green) (Pseudococcidae) on the islands of San Andres and Providence, Colombia with an updated taxonomic key to iceryine scale insects of South America. Insecta Mundi, (0265):1-17.

8. Lazaro-Castellanos, C., H. Gonzalez-Hernandez, J. R. Lomeli-Flores, S. N. Myartseva, L. D. Ortega-Arenas and S. Ochoa-Ascencio. 2012. Natural enemies of armored scale (Hemiptera: Diaspididae) on avocado Hass in Michoacan Mexico. Revista Colombiana de Entomologia, 38(1):6-13.

9. Navea, D. O. and R. M. Vargas. 2012. Parasitoidism rate and life table parameters of Aphytis diaspidis (Howard) (Hymenoptera: Aphelinidae) and its host latania scale Hemiberlesia lataniae (Signoret) (Hemiptera: Diaspididae). Chilean Journal of Agricultural Research, 72(3):338-344. 
10. Pena, J. E., Mohyuddin, A. I. and M. Wysoki. 1997. The current mango Pests' management in the tropics, Acta Horticulture, 45(5): 12-820).

11. Rugman-Jones, P. F., Morse, J. G. and R. Stouthamer. 2009. Rapid molecular identification of armored scale insects (Hemiptera: Diaspididae) on Mexican 'Hass' avocado. J. Econ. Entomol., 102(5):1948-1953.

12. Swirski, E. and M. Wysoki. 1995. Avocado pests in Israel. Proceedings of The World Avocado Congress III, pp. 419 - 428.

13. Wysoki, M., Izhar, Y., Swirski, E., Gurevitz, E. and S. Greenberg. 1977. Susceptibility of avocado varieties to the long-tailed mealybug, Pseudococcus longispinus (Targ. - Tozz.) (Homoptera: Pseudococcidae) and survey of its host plants in Israel. Phytoparasitica, 5(3): 140-148. 


\title{
حصر الحشرات القثرية والبق الدقيقى والاعداء الحيوية المرتبطة بها على أصناف الأفوكادو فى مصر لافي الهر
}

\author{
عباس سيف النصر يوسف ، عادل محمد سراج \\ معطر بحوث وقاية النباتات - مركز البحوث الزراعية - الدقى - جيزة
}

أجريت الدراسة الحالية لمدة عام ( يناير - ديسمبر ب ا ـ ب) على سته أصناف أفوكادو منزرعة

فى أراضى مستصلحة جديدة فى أربعة مناطق بأربعة محافظات (برج العرب بالأسكندرية والسادات

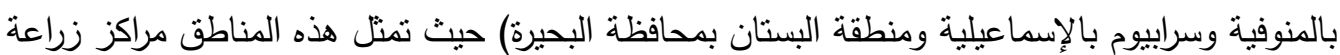

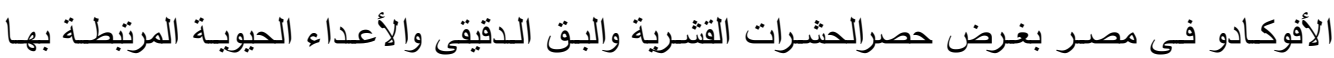

(طفيليات ومفترسات) ودرجة الإصابة على أصناف الأفوكادو الدختلفة فى مناطق الدراسة.

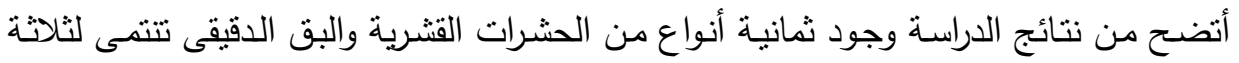
فصائل حشرية هى فصيلة الحشرات القثرية الرخوة وتضم الحشرة القنرية البنية الرخوة وحشرة البلفناريا،

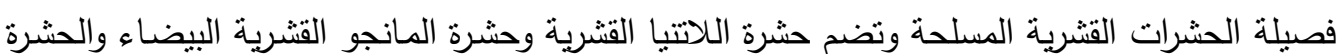
القترية الحمراء وحشرة التفلة القشرية وفصيلة البق الدقيقى الكاذب وتضم البق الدقيقى ذو الذنب الطويل

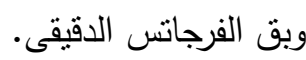

ومن الدراسة وجد طفيل Coccophagus scutellaris مصاحبا للحشرة القثرية البنية الرخوة ،

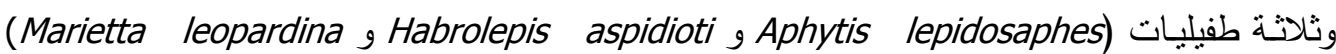

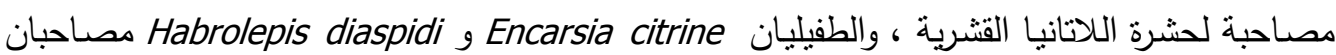

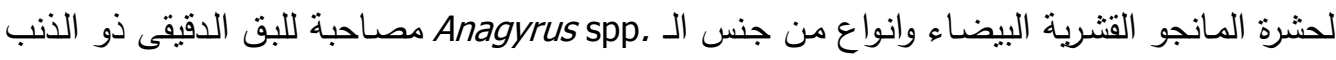
الطويل ومن المفترسات وجد الففترس Rodalia cardinalis مصاحبا لحشرة البلفناريا والمفترسـان Scymnus syriacus gryptolaemus montrouzieri

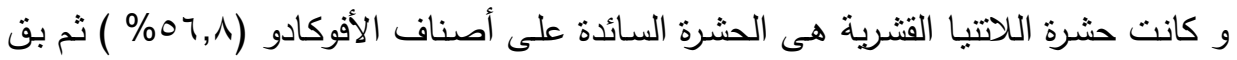

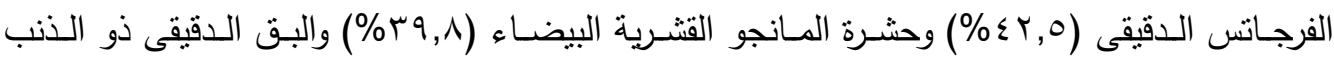

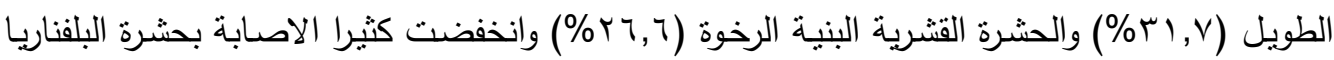

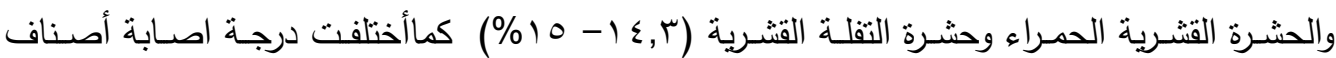
الأفوكادو بالحشرات القثرية والبق الدقيقى حيث كان الصنف هاس شديد الإصابة وكان الصنفين ولايم

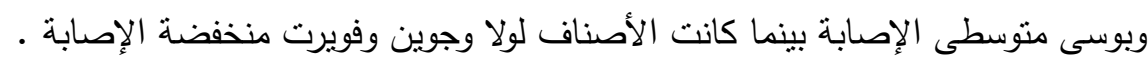

